\title{
$(\mathrm{cc})) \mathrm{BY}-\mathrm{ND}$
}

\section{The GIS Forma Urbis Romae Project: Creating a Layered History of Rome}

\author{
James Tice, University of Oregon
}

\begin{abstract}
Using advanced GIS technology and accepted scholarly methods, this multi-disciplinary project intends to create a layered history of Rome by updating Forma Urbis Romae, the cartographic masterpiece of ancient Roman topography published in 1901 by archeologist Rodolfo Lanciani. This extremely accurate map measures 25 by $17 \mathrm{ft}$ and uses an innovative graphic system that represents Rome's historic urban fabric as a series of transparent layers from ancient to modern. The map remains the standard archeological reference for Rome even though it does not incorporate archeological discoveries uncovered since its original publication 100 years ago. We plan to critically examine, update, and eventually republish the map as an interactive website that will also serve as a dynamic geo-database for scholars and others. Our project team will bring its considerable experience in Web-based design in the study of the humanities to ensure a highly intuitive product that is accessible, interactive, and expandable.
\end{abstract}

The GIS Forma Urbis Romae Project is a long term, multi-disciplinary effort involving archeology, art and architectural history, urban studies, cartography, history, and geography. It proposes to explore important aspects of the humanities using digital methods that can facilitate our understanding of history and place. The subject of this inquiry is Rome, and the object of our investigation is the cartographic masterpiece and pioneering study of ancient Roman topography, Forma Urbis Romae (fig. 1). Published in 1901 by the Italian archeologist Rodolfo Lanciani (1847-1929), this map sums up the rich cartographic tradition to be found for Rome. Today it remains the standard archeological reference for the city even though it does not incorporate the host of archeological discoveries that have come to light since its original publication. This phase of our work is being funded by an American Council of Learned Societies Digital Innovation Fellowship for the academic year 2012-2013. 


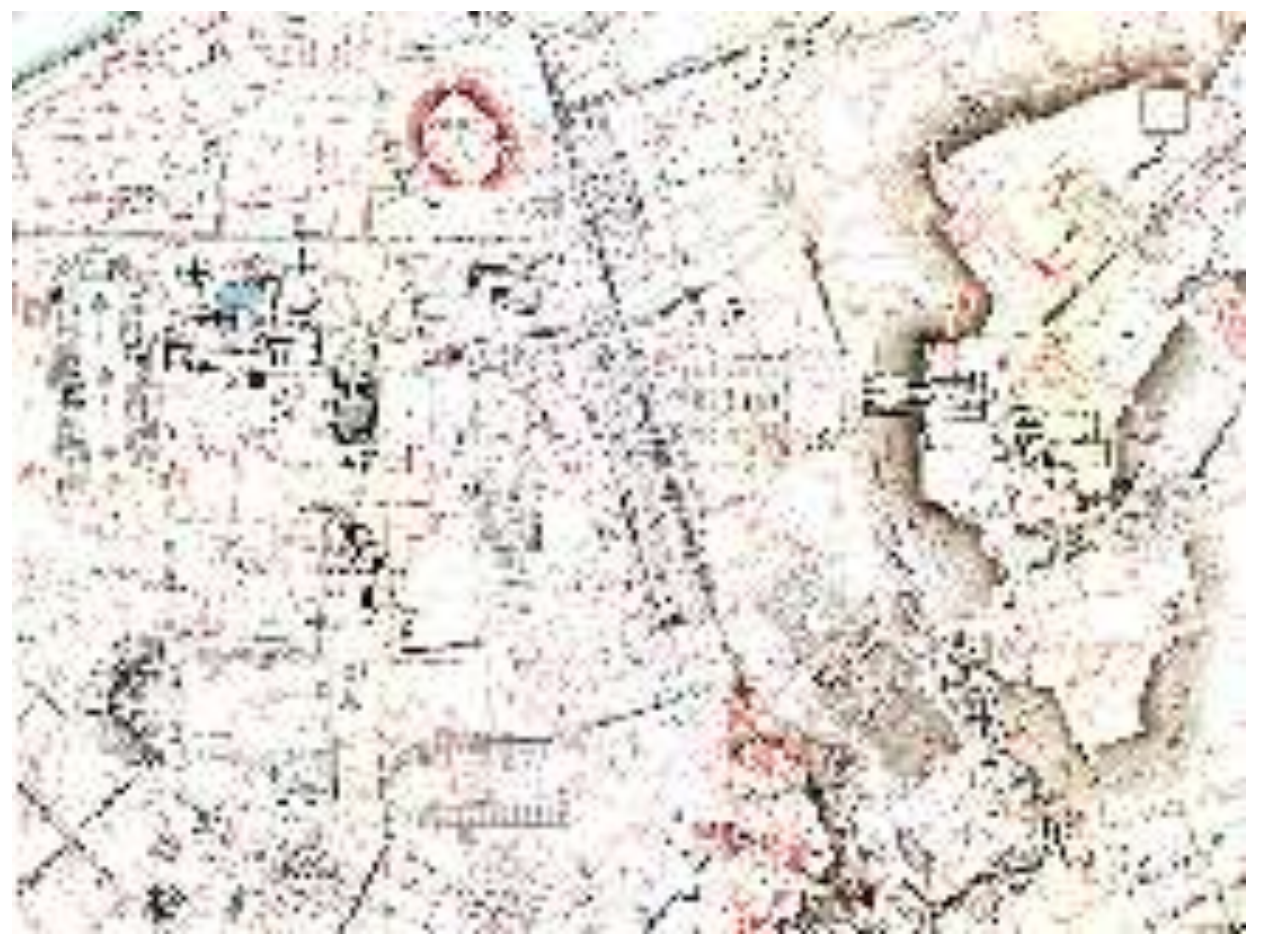

Fig. 1. Forma Urbis Romae, detail, Rodolfo Lanciani, 1901

We are critically examining, updating, and eventually republishing a new Forma Urbis Romae in the form of an interactive and dynamically evolving "geodatabase" that will document and represent the archeological foundations of the city and their subsequent manifestations in later epochs. In addition to an interactive digital product, our future plans contemplate print versions of the map through periodic releases, or a print-on-demand feature, to record important milestones in the ongoing investigation. Our goal for the Forma Urbis Romae Project is to create an accessible, robust geo-database that will preserve Lanciani's map in digital form. As a dynamically evolving digital database it will at once permit scholars to access information and invite them to contribute archeological evidence as it is discovered so that the map will accurately update and represent current research. 


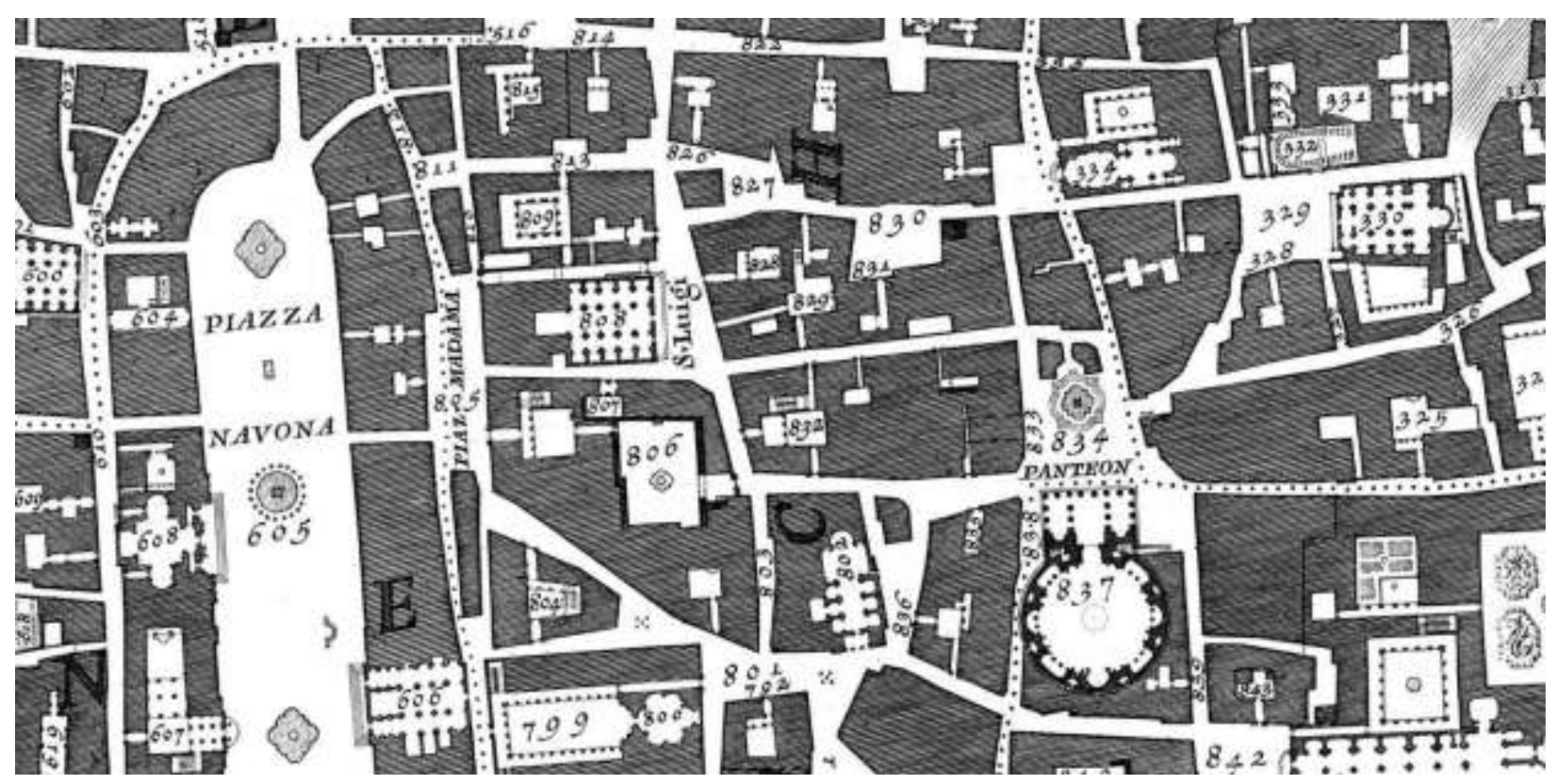

Fig. 2. La Pianta Grande, detail of the Campus Martius, Giambattista Nolli, 1748

\section{Background Description}

Forma Urbis Romae was issued in installments from 1893 to 1901. The map not only records the ancient city of Rome but also extensive cartographic detail about subsequent historical epochs including Early Christian, Renaissance and Baroque, and Modern. With his map, Lanciani paints a moving portrait of three millennia of human history in the longest continuously inhabited city in the Western world. No other city has been recorded in this fashion either in method, scope or scale. The map is drawn at $1: 1000$ and consists of 46 plates each measuring 25 by 36 inches, which, when combined, yields overall dimensions of approximately 17 by 24 feet, the largest map of Rome produced since the Severan marble plan, Forma Urbis, was created in the early third century AD. That monumental plan, almost four times the size of Lanciani's, served as an inspiration for his work; as evidence, the surviving fragments from it are duly drawn and incorporated into Lanciani's own map. Lanciani derived his idea in part from an earlier archeologist, Luigi Canina (1795-1856), who published his maps, Pianta di Roma Antica, in successive editions from 1830 to 1850. Canina used a layered technique for linking ancient monuments to the nineteenth-century city of his day and so set the precedent for Lanciani's legible and informative graphic method. Perhaps the most profound of all Lanciani's cartographic precedents is the 1748 Pianta Grande di Roma by Giambattista Nolli (fig. 2). This map was the first accurate map of Rome and one of the most influential city maps ever created. Its unsurpassed, meticulous detail of the Baroque city 
reveals important churches, palaces, and extant ancient monuments but also includes bridges, aqueducts, prisons, pawnshops, and even street drains (there are 1,320 sites identified in the index while an additional 700 names appear as text on the map proper, bringing the identified sites to well over 2,000). The Nolli map quite literally served as the base for Lanciani's map, as one can clearly see its appearance as the distinctive red layer in the Forma Urbis Romae plates.

Before examining the significance of Lanciani's work to our project, it is worth commenting upon his creative graphic technique especially since it bears directly upon our visualization methods. Being acutely aware of the stratified nature of Rome with its successive historical epochs, Lanciani captured this profound insight by devising the simple graphic measure of representing the city as a series of transparent layers, each one of which was color-coded for easy visual recognition (fig. 3). Taking advantage of late nineteenth-century innovations in lithography, his superimposed plans reveal a palimpsest with three distinct historical strata: Ancient and Early Christian (black), Renaissance and Baroque Rome (red), and Modern (light blue). This approach enables the observer to read, cumulatively as well as simultaneously, the temporal evolution of Rome.

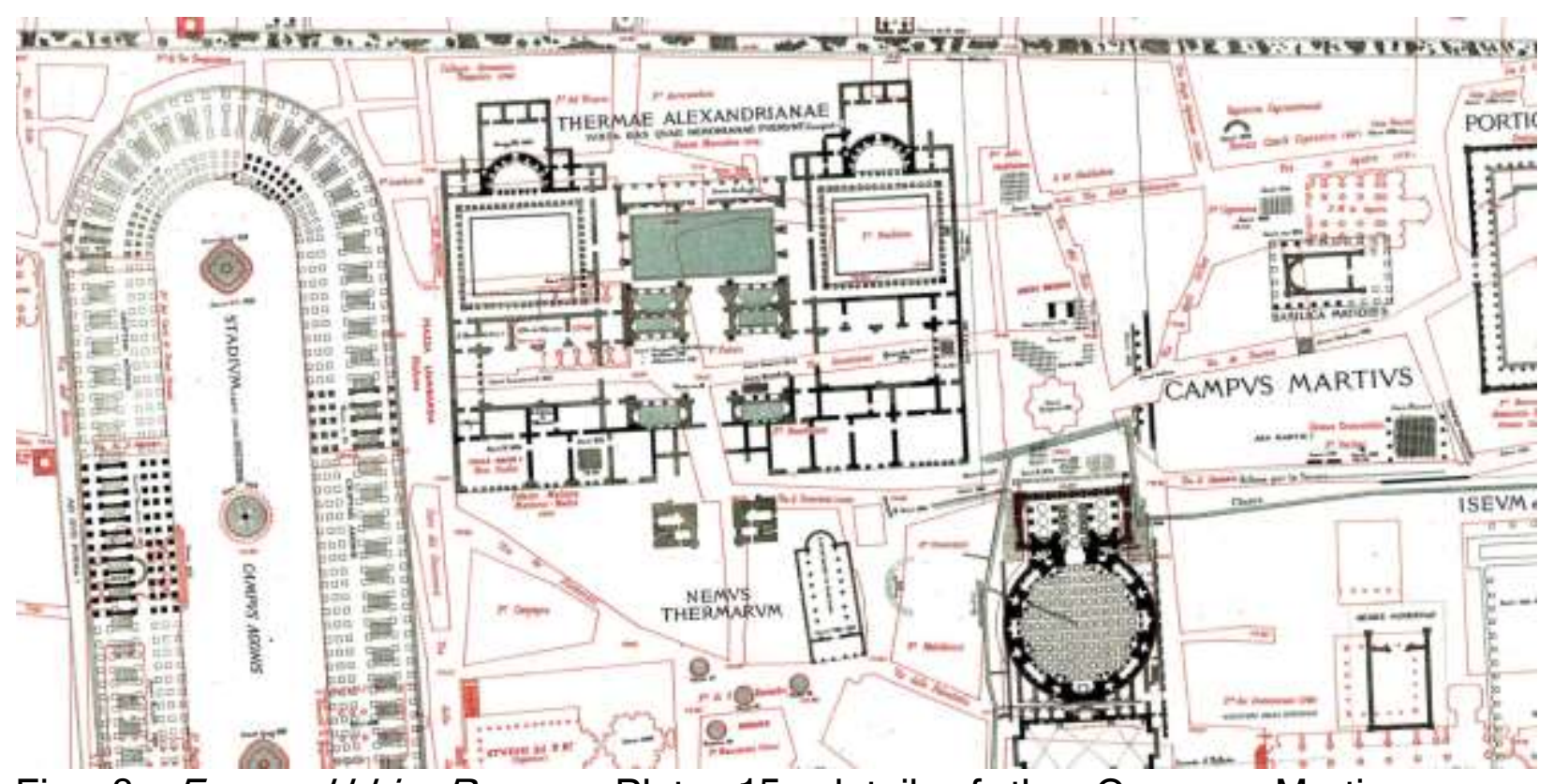

Fig. 3. Forma Urbis Romae, Plate 15, detail of the Campus Martius,

Rodolfo Lanciani, 1901 
Closer investigation shows how the layered method allows for complex historical and spatial relationships to become readily apparent. For example, in the Vatican the Lanciani map reveals how Nero's Circus (the place of St. Peter's martyrdom in the first century) served as a foundation for the fourthcentury basilica dedicated to that saint (in black) and how that structure in turn provided the armature for Renaissance and Baroque phases of construction of the basilica which culminated in the seventeenth-century architectural complex (in red).

\section{Significance of the Forma Urbis Romae Project}

The Lanciani map is an important cartographic resource for several reasons. Conceptually, it provides a comprehensive historical framework of Rome showing spatial relationships horizontally (for places within a given time frame) and vertically (for specific places over time). Lanciani's map was the first to provide a comprehensive plan of the ancient city that accurately represented its constituent elements in their correct spatial relationship and in relationship to one another within the limits of known archeological scholarship of his day. It was also the first map of Rome to demonstrate a comprehensive layered understanding of the city that revealed how places in Baroque and Modern Rome were actually shaped by the ancient structure of the city. This aspect of the map highlights the remarkable staying power of ancient structures that have influenced subsequent urban form. For example, Lanciani reveals how the configuration of Piazza Navona with its later Baroque embellishments closely follows the footprint of Domitian's third-century stadium on whose foundations it was constructed. While this relationship is well known, his visual depiction of it clarifies one's understanding and provides a vivid graphic analysis of the spatial evolution of these sites.

Lanciani's map was inclusive in its representation of building types and other features. A heterogeneous array of structures such as temples, basilicas, palaces, insulae (housing blocks), granaries, baths, sports complexes, and even ancient trash dumps are shown with remarkable attention to detail. The city's infrastructure was given equal weight as the depiction of streets, water cisterns, aqueducts, bridges, and street drains testify. Taken as a whole, this comprehensive, layered representation of Rome is unsurpassed for the wealth of information it portrays and the incisive clarity it achieves.

Over a century has passed since Lanciani published Forma Urbis Romae. To his credit it still remains the most important map of ancient Rome ever produced and is therefore still prized as a resource by scholars and historians. Details of the Lanciani map continue to be published in scholarly works to the 
present day with all the errors and omissions of the original. Three subsequent reprints of the original map were published in 1990 and 2007 (by Quasar). None of these publications, however, update content. The continuing interest in Lanciani's work and the desire to bring it up to date has inspired at least three failed attempts by scholars in the last half century. From our particular vantage point of rigorous spatial analysis and visualization, the most serious limitation of all these attempts (besides their incompleteness) is that they lack the graphic sophistication and immediacy that is the goal of the Forma Urbis Romae Project. These well-intentioned but ultimately less than satisfactory trials demonstrate the continuing interest in Lanciani's work, its permanent scholarly value, and the demand for an updated, accessible, and dynamically evolving Forma Urbis Romae.

\section{Challenge and Current Status of the Project}

Besides lacking currency, the 1901 Lanciani map has limitations imposed by the medium in which it was realized: the printed book. The large plates can be cumbersome to handle. It is a trying experience to focus on a zone of the city if it includes multiple plates, separated as they are by distracting joints, or more difficult still, distanced by several pages in the bound version. Printing technology in the late nineteenth century limited Lanciani to three colors and thus the complexity of the city was somewhat arbitrarily reduced to the same number of temporal layers. Annotations were limited by space available so that textual notes did not obscure drawings (these are referenced to the remote seven-volume text that Lanciani published to accompany his map). Most problematically, Lanciani's map is difficult to update, as we have noted above, and therefore unable to grow with the expanding body of knowledge that in principle it was dedicated to reveal. The fact that the 1901 version has not changed in 110 years is a testament to the inertia that may result when reliance is placed exclusively on print media. Our project hopes to demonstrate that all these limitations can be overcome with the knowledgeable use of advanced digital media as it facilitates historical research. The Forma Urbis Romae Projects cartographic interface allows for seamless display and intuitive navigation from the macro scale of the city to the micro scale of individual monuments and details. The numbers of layers employed are theoretically limitless. At the very least, the city's stratification could encompass eight layers that would cover important epochs: Kingdom, Republic, Empire, Early Christian, Medieval, Renaissance and Baroque, Roma Capitale (the period that followed the city's annexation to Italy) and Contemporary. In the electronic form under construction for the Forma Urbis Romae Project, it will also be possible to access textual information (such as the detailed excavation notes 
mentioned above) unobtrusively and efficiently by a simple click of the mouse on a specific site. While the limitations of print media have made past attempts to update the map obsolete by the time they reached the printing presses, the digital database we envision invites constant updates in a naturally evolving format.

Using state-of-the-art GIS technology we are critically examining, refining, and updating the Forma Urbis Romae. It is now possible to augment its content so as to incorporate the most current scholarship available. At the University of Oregon, we are uniquely poised to accomplish this ambitious task based on our track record that brought two other major spatial historical resources to the Web: "The Nolli Map Interactive Website" published in 2005, focusing on the cartography of eighteenth-century Rome, and our most recent "Imago Urbis: Giuseppe Vasi's Rome" published in 2007. The latter effort culminated in a major traveling exhibition, Giusepe Vasi's Rome: Lasting Impressions from the Age of the Grand Tour. The show, curated by James Tice and James Harper with digital installations by Erik Steiner, Creative Director of the Spatial History Project, Stanford University, and Ken Kato of the InfoGraphics Lab, opened at the Jordan Schnitzer Museum of Art at the University of Oregon in 2010 and traveled to the Princeton University Art Museum in 2011.

With the advent of innovative digital tools we have seen significant advances in the ability to manage, manipulate, and measure geographic data, and yet only minor advances in cartographic design have resulted. In essence, our approach exploits Lanciani's representational methods to enhance our updated Forma Urbis Romae by taking advantage of current digital tools such as GIS, advances in Web technology, and contemporary satellite imaging resources such as Bing Maps (figure 4). 


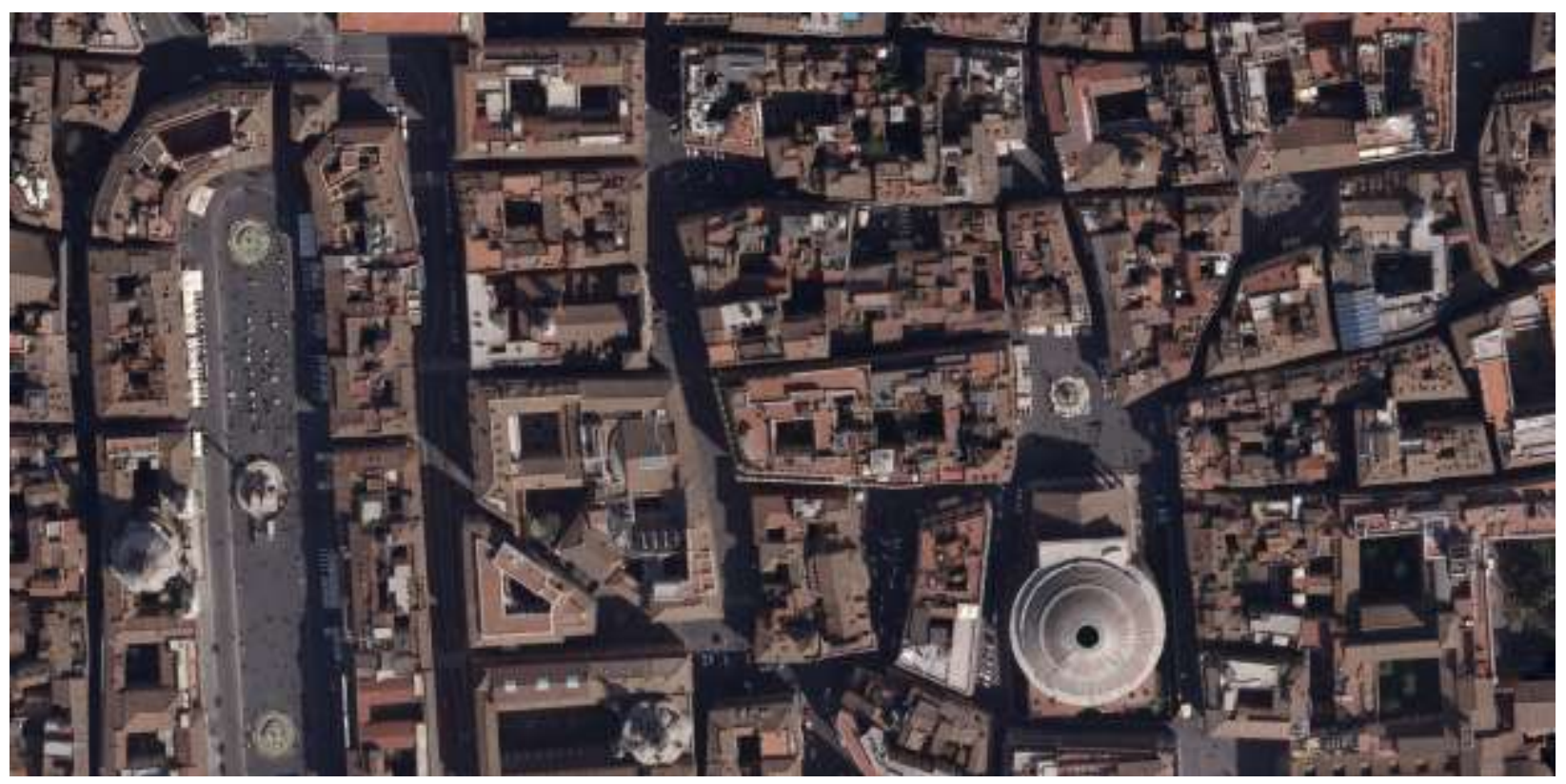

Fig. 4. Contemporary Map of Rome, detail of the Campus Martius, Bing Maps, 2012

Our chief task involves rendering the graphic and attribute contents of Lanciani's original map into a dynamic spatial database and doing so accurately, using state of the art GIS tools. Building on our assets of the historical and modern GIS layers of Rome, the ongoing geo-database will become a platform to examine spatio-temporal data from any epoch in Rome's history. In addition to this database, we intend to develop a first iteration of an interactive website (using either Flash or Drupal) that will allow users to explore and query layer upon layer of the updated map. Our work takes advantage of the unique strengths of the technical team specializing in Web design, programming, and GIS, using the most current technology for managing geospatial data and presenting it on the Web. Not coincidentally, the project will be hosted at the University of Oregon, one of the leading geographic research infrastructures in the country.

We are in the process of assessing the accuracy and currency of Lanciani's map. This is being accomplished using two processes. The first is scientific. It is now possible to geo-rectify (carefully align or "rubber sheet") historic maps such as Lanciani's using GIS software (ArcGIS). A preliminary has been accomplished so that the Forma Urbis can now be geo-referenced (crossreferenced topographically) with contemporary satellite imaging and coordinated with other scientific surveying techniques in addition to the several dozen original cartographic layers of Rome in our collection.

The second aspect of the work is to critically examine historical and archeological evidence uncovered since 1901. Relying on our own expertise and that of our expert consultants, this information is being geo-referenced into the 
map. Using a rigorous system to control and verify data in order to correct and amplify Lanciani's work, we are bringing it into correspondence with the most authoritative information available, a development we are sure that Lanciani himself would have approved. A substantial proof-of-concept has been completed. The following section details what we have accomplished to date.

\section{Work Accomplished}

The 46 plates from the original Forma Urbis Romae have been scanned at high resolution using the detailed 1:1000 scale original edition. These plates have then been digitally "stitched" together to form one large, seamless map, in effect creating a digital facsimile of the original plates composed as one unified document. As far as we are aware, our printing of that file in 2008 is the first time the map has appeared as a single sheet, albeit in much reduced form (approximately 42 by 60 inches). This preliminary task would have been much more difficult to achieve before sophisticated digital tools were available. This version of Lanciani's map was first presented at the conference "Descriptio Urbis: Measuring and representing the modern and contemporary city" held in Rome in 2008. The newly assembled Lanciani map provides us with a template that has become the basis for separating or "delaminating" the layers of the original map itself. Using our copyrighted Nolli map, the Medieval/Renaissance/Baroque "red layer" has been extracted as a vectorized_(scalable) slice and then reinserted into the Lanciani master, thus providing a more dynamic and reliable base. Furthermore, we have geo-rectified (rubber sheeted) the Nolli layer with satellite imagery (Bing Maps is now state of the art for many cities, including Rome) as a separate layer, reaffirming that a high degree of congruence exists between the two. These updated layers provide an accurate, scientific base for the work that follows. 


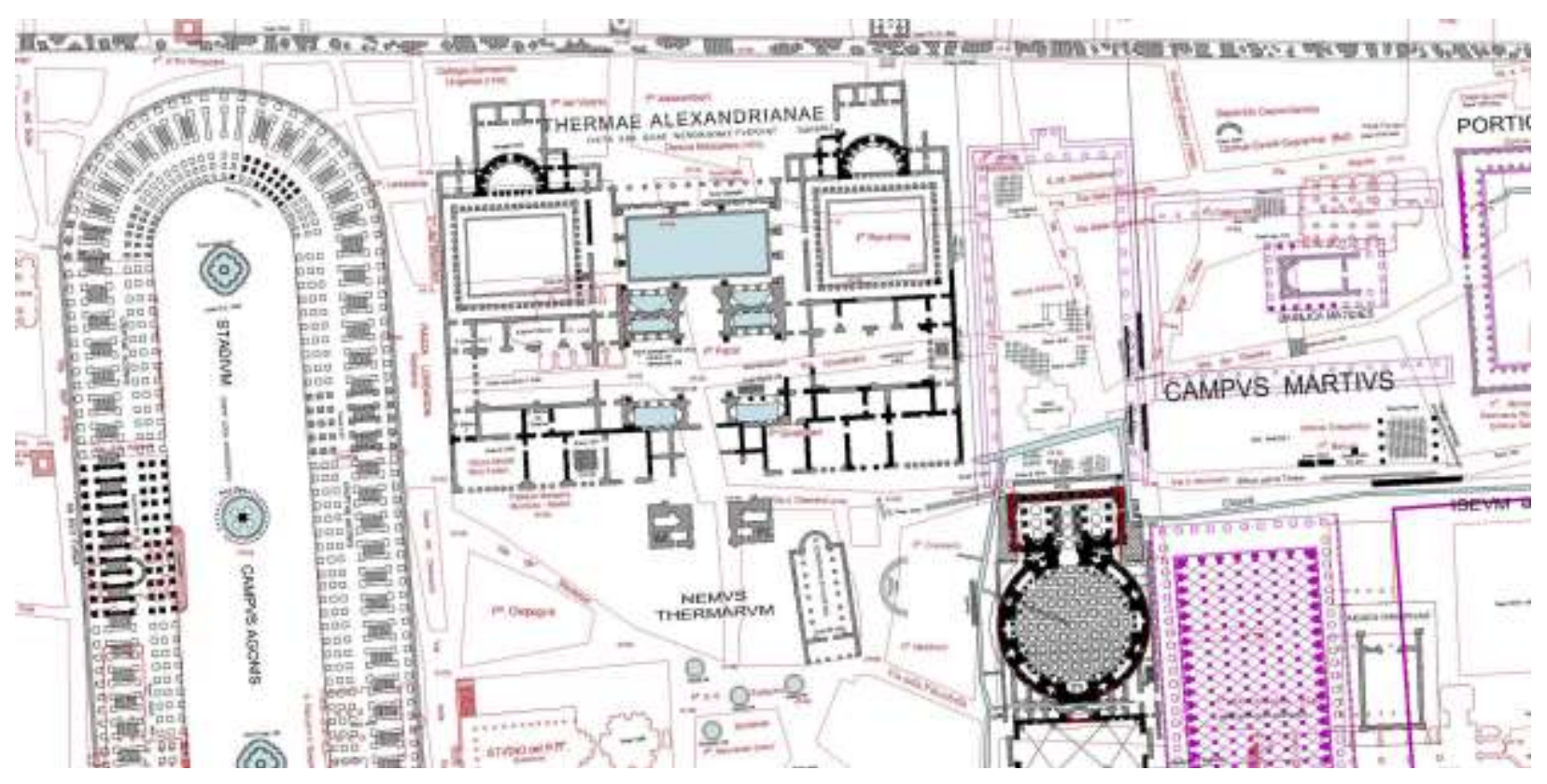

Fig. 5. University of Oregon Forma Urbis Romae, detail Campus Martius (with updates), 2012

Beyond work on the map as a whole, we have chosen Plate 15, one of the 46 plates in the historic center, as a trial segment to explore how we might analyze, represent, and subsequently treat the remaining 45 plates in the future (fig. 5). We selected this plate because it is especially rich in Ancient, Medieval and Baroque monuments. This zone accurately encompasses welldocumented landmarks, such as the Pantheon, the Piazza Navona/Stadium of Domitian and the Alexandrian Baths, which can then act as a control for other plates. The same segment, however, also displays very noticeable inadequacies. For example, Lanciani incorrectly locates the Saepta Julia (an ancient voting precinct now established as being next to the Pantheon) over a hundred meters away along the Via del Corso. A host of archeological discoveries that have come to light since Lanciani's publication do not, of course, appear.

Using this circumscribed yet key map segment we have been able to examine the city, level by level. We have succeeded in "delaminating" the multiple layers that Lanciani identified: Ancient, Early Christian (black); Medieval/Renaissance and Baroque (red) and Modern, in Lanciani's day (blue). Additional layers will show changes since Lanciani's time. It would not be difficult to create sub-layers for the major divisions. For example, we could focus on ancient Rome during the reign of Augustus (27 BC-14 $A D$ ) or, if we wished to switch from a temporal perspective to a topographic/typological mode, we could create a layer that simply focuses on the Roman street system from antiquity to the present. We have begun to scrutinize the results, testing the extent to which 
the separated layers-now readily examined in their "pure form"-agree with scholarly research that has come to light since the original publication.

The results of our trial example have been illuminating. After consulting contemporary scholarship by F. Coarelli (Roma [Guida Archeologica], 2005); L. Haselberger, (Mapping Augustan Rome, 2002); E. Steinby (Lexicon topographicum urbis Romae, 1993 - 2000) among others, we have corrected errors in placement and faulty reconstructions in the trial segment of Lanciani's map. Our test case highlights these corrections and other additions so they become apparent to the viewer. These and many other potential amendments to the 1901 map demonstrate that an updated, dynamic version of Forma Urbis Romae is an achievable goal. Another important aspect of the Forma Urbis Romae Project is the manner in which Lanciani's cartographic image is linked to textual information. His seven-volume Storia degli Scavi (History of the Excavations) has been digitally linked, in part, from the Internet Archive (Getty Research Institute).

As part of the re-mastered map, we have digitally prepared and georeferenced the following maps for a portion of the map: the third-century Severan Marble Plan; the 1748 Nolli Map (completed); the 1901 Forma Urbis Romae (completed); SARA Nistri Photogrammetry from the 1950s; and the contemporary Bing Satellite Image (completed). We will construct new layers for the following: Ancient Rome, Early Christian Rome, Medieval, Renaissance and Baroque Rome, Modern Rome and twentieth-century Rome. Each new layer reflects current scholarship and also makes evident the errors and gaps in the original Lanciani map. In addition we have incorporated a portion of the Storia degli Scavi and linked it to the re-mastered Forma Urbis Romae.

\section{Geospatial Database Management and Visualization Design}

The Forma Urbis geo-database will build on our already robust GIS infrastructure developed over the last decade in collaboration with the InfoGraphics Lab at the University of Oregon. The lab's facility and expertise in managing geospatial data for research and infrastructure projects has been an essential ingredient in the success of our prior work. The lab maintains an "always on" enterprise-level ESRI ArcSDE geodatabase and ArcGIS server to manage the University of Oregon Facilities Services Department GIS infrastructure for campus mapping, emergency management, and facilities maintenance. This server also houses and serves all of the geographic data for our previous digital projects treating the cartography of Rome, as well as several research projects at Stanford's Spatial History Lab, ensuring a powerful collaborative infrastructure for academic research uncommonly found in academic settings. Data may be inputted simultaneously by multiple users from any location over a secure connection, and several levels of user rights management may be implemented 
thus facilitating remote collaboration between the three venues of our work: the University of Oregon, Stanford University and Studium Urbis (Rome).

Our team is experienced in the area of cartographic and visualization design, particularly with the interactive Web-based maps. With such an emphasis placed by Lanciani on clear visual representation, we expect to match this standard of legibility and enhance it with interactive features such as animation, linking, and brushing (i.e., interactive filters, for example, by construction date). In concert with ArcGIS software we are using a suite of graphic design and programming tools to re-master the Lanciani map in its updated form (e.g. Adobe Illustrator, Photoshop, and Flash/Flex). While we plan on matching the visual accessibility of the original map, we will ensure its dynamic nature in the future by recording all elements in a vector database (rather than rasterized versions), which is scalable and versatile (fig. 6).

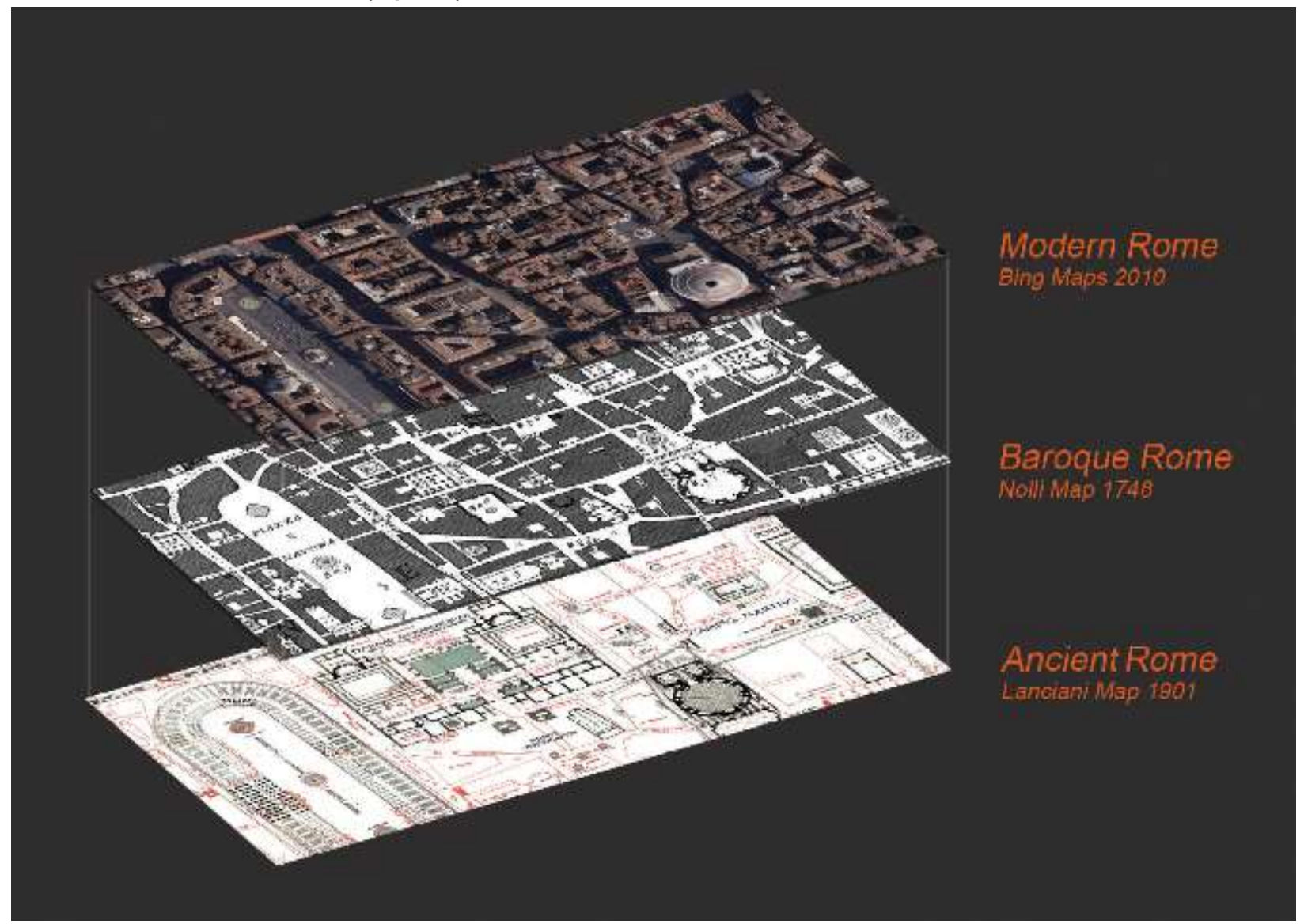


Fig. 6. Layers of History Diagram: Modern Rome, Baroque Rome, and Ancient Rome (graphics by J. Tice)

\section{Web Development, Collaboration, and Institutional Support}

The final key area of expertise required to implement the Forma Urbis Romae Project will be in Web development. While our previous two projects continue to function adequately, Web technologies are fast developing to support more dynamic sites that are rapidly updated and implement re-configurable modules. In particular, we are contemplating the use of Drupal as an appealing open-source platform with which to develop the site. The Spatial History Project has recently completed a major Drupal-based site (http://spatialhistory.stanford.edu/cgi-bin/railroaded/) that includes a user-friendly backend content management system. The support for Drupal is strong at Stanford, and there is a large pool of developers with which we intend to consult. As we have for our previous work, we also anticipate continuing to use ActionScript and Adobe Flash, which is still the most ubiquitous, engaging, and robust Web platform for interactive and animated graphics. Finally, we intend to take advantage of the Web-mapping tools offered by ESRI built on top of ArcGIS Server (programmed in Flex, Silverlight or JavaScript). In addition to a variety of other sophisticated GIS analyses, these tools support basic viewing, querying, and live editing of geographic data. All our work will be in the public domain and freely accessible on the Web.

The Forma Urbis Romae Project is a multi-disciplinary, collaborative project that brings together three individuals who represent the study of archeology, architectural history, architecture, geography and geographic information systems. The overarching interests that all team members have in common are those revolving around the spatial history of place over time and its visualization using digital media. The advantages of this collaboration are twofold: the benefit from individual expertise and also from the assets of collaborators' home institutions. Professor Allan Ceen is director of Studium Urbis, a unique research institution in the heart of Rome. With its extensive archive of historic maps and library, it specializes in the urban history of Rome. Since its founding in 2000 the director has authored numerous articles and exhibitions that treat the rich legacy of Roman urbanism, architecture, and history. Erik Steiner is the creative director of the Spatial History Project at Stanford University and has led a number of multidisciplinary research projects that use GIS technology to explore the humanities and social sciences. James Tice, the principal investigator, is professor of Architecture at the University of Oregon. Along with those colleagues mentioned above, he produced the award-winning website, "The Interactive Nolli Map Website" in 2005 and more recently "Imago Urbis: Giuseppe Vasi's Grand Tour 
of Rome" in 2007. The Nolli map website in particular has enjoyed success with scholars and students around the globe and has been featured in various venues including the Victor and Albert Museum in London and the Université du Québec in Montreal.

It is intended that the Forma Urbis Romae Project will allow scholars from around the world to participate in updating and verifying topographic information about the city of Rome. Since digital media is rapidly becoming the lingua franca of contemporary cartography, this consortium of scholars, digital designers, and institutions will have a collective power beyond what any one individual could achieve. Colleagues at Stanford University, the University of Rome, Penn State University, and other institutions have endorsed our research to date. We believe we are now poised to consolidate our work and will be able to attract major funding from other sponsors. We also believe that the interdisciplinary nature of our work will foster connections among a variety of disciplines that will lead to fruitful curricular development and exchange.

\section{Works Consulted}

Ashby, T. The Aqueducts of Ancient Rome. Oxford: Clarendon Press. 1935. Print.

Benevolo, L. L'Area Archeologica Centrale e la Città di Roma. Roma: De Luca Edizioni d'Arte. 1988. Print.

Carettoni, G. La Pianta Marmorea Di Roma Antica. 2 vols. Roma: Ripartizione del Comune di Roma. 1960. Print.

Carandini, A. Atlante di Roma antica. 2 vols. Roma. 2012. Print.

Castagnoli, F. Roma Antica: profilo urbanistico. Roma: Jouvence. 1978. Print.

Coarelli, F. Roma [Guida Archeologica], Roma. 2005. Print.

Frutaz, A.P. Le Piante di Roma, 3 vols. Roma: Instituto di studi romani. 1962. Print. 
Gatti, G. Archeologia. Roma. 1911. Print.

Giglioli, G. Museo della Civiltà Romana. Roma: Comune, Rip. Antichità e Belle Arti. 1964. Print.

Guidoni, E. L'urbanistica di Roma. Roma: Laterza. 1990. Print.

Haselberger, L. Mapping Augustan Rome. Portsmouth, RI: Journal of Roman Archaeology. 2002. Print.

Krautheimer, R. Rome: Profile of a City. Princeton, NJ: Princeton University Press.1980. Print.

Lanciani, R. The Destruction of Ancient Rome. New York: Macmillan Co. 1899. Print.

---. Forma Urbis Romae. Roma: Quasar. 1901. Print.

---. The Ruins and Excavations of Ancient Rome. Boston: Houghton Mifflin. 1897. Print.

---. Storia degli Scavi, vols.1-4. Roma: Quasar. 1902-1912. Print.

---. Storia degli Scavi, vols. 5-7. Roma: Quasar. 1994-2002. Print.

Manacorda, D. Crypta Balbi. Milano: Electa. 2001. Print.

Marigliani, C., ed. Le Piante di Roma delle collezioni private. Roma: Provincia di Roma. 2007. Print. 
Nash, E. Pictorial Dictionary of Ancient Rome. London: Thames \& Hudson. 1968. Print.

Richardson, L. A New Topographical Dictionary of Ancient Rome. Baltimore: Johns Hopkins University Press. 1992. Print.

Rodriquez Almeida, E. Forma Urbis Marmorea. 2 vols. Rome: Quasar. 1981. Print.

Steinby, M. E. Lexicon topographicum urbis Romae. Roma: Quasar. 1993-2000. Print.

Valentini, R. and G. Zucchetti. Codice Topografico della città di Roma. Roma: Tipografia del Senato. 1940-1953. Print.

\section{Web Site Bibliography}

Frischer. B., ed. "Rome Reborn." University of Virginia. 2010. Web. $<$ http://www.romereborn.virginia.edu/>.

Rinne, K., ed. "Aquae Urbis Romae: The Waters of Rome." University of Virginia. 1998-2012. Web. <http://www3.iath.virginia.edu/waters/>.

"Stanford Digital Forma Urbis Romae Project." Stanford University. 2002-2003. Web. <http://formaurbis.stanford.edu/index.html>.

Tice, J., E. Steiner and A. Ceen. "The Interactive Nolli Map of Rome Website." University of Oregon. 2005. Web. <http://nolli.uoregon.edu/>. 